\title{
Factors Affecting the Academic Achievement of the Secondary School Students
}

\section{Daniel D'souza $^{1^{*}}$ and Sunita Magre ${ }^{2}$}

Research Scholar ${ }^{1}$ and Professor \& Research Guide ${ }^{2}$, Department of Education Department of Education, University of Mumbai University of Mumbai, India

*Corresponding author: danny.dsouza10@gmail.com

Received: 14 Sept., 2021

Revised: 27 Nov., 2021

Accepted: 12 Dec., 2021

\begin{abstract}
Students' academic performance is affected by several factors which include students' learning skills, parental background, peer influence, teachers' quality, learning infrastructure among others. The researcher in this research has used four factors - Parents attitude, Student's attitude towards learning, Peers attitude and Teacher's attitude. The research was conducted on the secondary school students of Mumbai and Thane. The survey conducted was validated and the study confirmed that none of the variables had significant relationship with the academic achievement of students. The results thus interpreted were that the factors did not necessarily affect the academic achievement of secondary school students. Further, the researcher correlated the factors, it was found that there was significant relationship between the factors where one factor increases the other factor too increased.
\end{abstract}

Keywords: Academic achievement, Parents attitude, Student's attitude, Peers attitude and Teacher's attitude

Academic achievement was once thought to be the most important outcome of formal educational experiences and while there is little doubt as to the vital role such achievements play in student life and later (Moore, 2019). In present days academic achievement plays a vital role in any individuals life time. Academic Achievement is one of the major factors considered by employers while hiring employees for their company. Thus, students have to put on good grades in their study to put on good grades to get an admission in reputed institutes and a good job in the long run. Poor Academic 
performance spells doom for the student whose life becomes uncertain and full of misery. Students' academic performance is affected by several factors which include students' learning skills, parental background, peer influence, teachers' quality, learning infrastructure among others. Government efforts to improve academic performance have led to series of interventions like scholarship, training of the lecturers, providing of infrastructure and so on. Majority of people chose academic achievement as it gives knowledge and the skill to survive and to be a better citizen towards one's country. Academic achievement differs from system to system or from country to country.

\section{Need and Rationale of the study}

The factors affecting the academic achievement of student plays a vital role in shaping the future of a student. Thus, it is important to understand as to what extent these factors affect them. It is to detect the factors and focus on them so that student's achievement in academics increases. Thus, it will help the students to fare well in their academics. It will also help the Parents and teachers to improve in their attitude towards the academics of their students. Moreover, it will help the Secondary school educational institutes to make policies and rules which will again help the students in their academics.

The study is conducted in the Secondary Schools only because in the previous researches it has been found that the academic achievement of the student decreases once the student comes to the secondary section in the schools. The researcher therefore has taken the task of conducting research on it. One needs to understand the factors and the reasons behind the academic achievement of students.

\section{Review of Related Literature}

The researcher reviewed various researches of factors affecting the academic achievement. A study (E.E. Ebenuwa-Okoh, 2010) on the academic achievement. This study examines the influence of age, financial status and gender on Academic Performance among undergraduates. A study (Mushtaq, 2012) on the factors affecting academic achievement. The focus of this research is that student performance in intermediate examination is linked with students' outline consisted of his approach towards communication, learning facilities, proper guidance and family stress. A study (Chazen, 2020) on factors affecting students' Academic Performance in 2020-2021. In this article factors such as students' situation at home, family status and new teaching methods were studied.

A study (Olufemi, Adediran \& Oyediran, Factors Affecting Students' Academic Performance in Colleges of Education in Soutwest, Nigeria, 2018) This study was carried out to assess factors affecting students' academic performance in Colleges of Education in southwest, Nigeria. A study (Sirin \& Sahin, 2020) on factors affecting the success of university students. In this study university students were analysed by logistic regression analysis. A study (Iman, 2017) on the Factors affecting students' academic achievement and experiences. The article states that Factors like Teacher student relationship, sleep, Commuting to University, Job during studying play a vital role in the academic achievement. A study (Lawal, 2010) on the factors affecting academic Achievement of students in Senior School Certificate Examination in Christian Schools. A study (Dev, 2016) on the factors affecting the academic achievement: A study on 
the Elementary School Students of NCR Delhi, India. The foremost aim of the study was to investigate and analyze the relationship of General Mental Ability, Interest and home environment with Academic Achievement. A study (Apu, 2020) on the Factors affecting students' academic achievement in Chemistry: A Case of Obudu Local government Area. Student's attitude and interpersonal relationship were tested using Pearson product moment correlation co-efficient analysis. A study (Son \& Cho, 2020) on the Factors affecting the academic Achievement in Globalized Environment. The purpose of this study is to examine the factors affecting the academic achievement of international students in degree programs in global education environment. A study (Hunter, 1965) on some factors affecting Undergraduate Academic Achievement. This article focuses on the factors in the student and the medical school which influence the academic performance at one medical school. A study (Sangkapan \& Laeheem) of factors affecting academic achievement into Probation Status at Prince of Songkla University. The study aims to investigate the academic achievement of students who were put in probation status. An analysis (Chinmayee, Manohar, \& Sayeeqa, 2016) on the factors affecting student academic performance using data mining techniques. The study aims to search out the major factors that may have an effect on a student's academic performance.

\section{Statement of the Study}

Factors Affecting the academic Achievement of the secondary school students.

\section{Operational Definitions of Terms}

In this study the key factors are the main concepts used and hence below described are the definitions of the key factors:

Factors: For this study the meaning of Factors are the things that affect the student in achieving academic scores. They are as follows - Attitude of students towards academics, Parents level of education (attitude of Parents) and size of the family, Peer attitude, Teacher student attitude. It plays a vital role in deciding the academic score and in the long run the success of the student in terms of getting an appropriate job. It also means one of the things that affects an event, decision, or situation.

Affecting: For this study the meaning of Affecting is an impact of the factors on the academic achievement of students. It shows the how factors play a role in transformation of a student's achievement, either transforming and increasing his scores or decreasing his scores.

Attitude: For this study the meaning of attitude is the feeling or opinion of students towards academics, it will reveal how the students feel towards their studies, which will contribute towards the achievement of their academics and towards their goal in the long term. Attitudes are often the result of experience or upbringing, and they can have a powerful influence over behavior. While attitudes are enduring, they can also change. 
Learning: For this study learning is the acquisition of knowledge, subject matter, information, understanding, and skill from teaching. It provides essential knowledge that is useful to achieve academic scores.

Peers: For this study peers are the students who belong in the category of Secondary school section. It also means students belonging to the same class in the secondary section due to the same age, grade or status. It is one of the factors that influence the students' academic achievement.

\section{Aim of the Study}

The aims of the current research are to understand which factors play a role in affecting the student's academic growth in the secondary schools:

To understand how the student's attitude towards learning affects the academic scores in Secondary school.

To understand the belief of students learning in reaching the goal set by them in Secondary school students.

To understand student's efforts in their academics in the different situations that they are placed in Secondary Schools

To understand the role of Peers in student's effort towards achieving academic scores in Secondary Schools

To understand the teacher's attitude towards the student's academic growth in Secondary schools.

To understand how Parents level of education affects the academic achievement of a students in Secondary schools.

To understand how the size of the family affects the academic achievement of students in Secondary schools.

\section{Objectives}

The objectives of the study were carefully considered keeping in mind the population of the study:

1. To compare the dimensions of factors affecting the academic achievement of secondary school students.

2. To study the dimensions of Parents level of education and size of the family affecting the academic achievement of secondary school students.

3. To compare the Attitude of Parents affecting the academic achievement of secondary school students on the basis of Gender. 
4. To compare the attitude of students affecting the academic achievement of secondary school students on the basis of Gender.

5. To compare the attitude of Peers affecting the academic achievement of secondary school students on the basis of Gender.

6. To compare the attitude of Teacher student relationship affecting the academic achievement of secondary school students with respect to gender.

7. To compare the Attitude of Parents affecting the academic achievement of secondary school students with respect to Grade

8. To compare the attitude of students affecting the academic achievement of secondary school students with respect to Grade

9. To compare the attitude of Peers affecting the academic achievement of secondary school students with respect to Grade.

10. To compare the attitude of Teacher student relationship affecting the academic achievement of secondary school students with respect to Grade.

\section{Hypothesis of the Study}

1. There is no significant difference between the attitude of Parents affecting the academic achievement of secondary school students with respect to boys and girls.

2. There is no significant difference between the attitude of students affecting the academic achievement of secondary school students with respect to boys and girls.

3. There is no significant difference between the attitude of Peers affecting the academic achievement of secondary school students with respect to gender.

4. There is no significant difference between the attitude of Teachers affecting the academic achievement of secondary school students with respect to gender.

5. There is no significant difference between the Attitude of Parents affecting the academic achievement of secondary school students with respect to Grade

6. There is no significant difference between the attitude of students affecting the academic achievement of secondary school students with respect to Grade

7. There is no significant difference between the attitude of Peers affecting the academic achievement of secondary school students with respect to Grade.

8. There is no significant difference between the attitude of Teacher student relationship affecting the academic achievement of secondary school students with respect to Grade. 
9. There is no significant relationship between the factors affecting the academic achievement of secondary school students.

\section{Scope and Delimitation of the study}

This research is only limited to Secondary School students and therefore limiting its use for this study. It has been taken into account certain age group of students in Secondary school that is from 10 to 14 years of the required age for this study. Students from Std $6^{\text {th }}$ to $\operatorname{Std} 10^{\text {th }}$ from secondary schools were considered for this study. This study did not consider students from Pre-Primary, Primary section of schools. The study has also not considered IGCSE and IB boards.

\section{Methodology of the Study}

The descriptive research method included under the quantitative paradigm has been used in the present research. A Purposive sampling method was used to collect the sample, where the researcher selected the secondary school students of the $6^{\text {th }}, 7^{\text {th }}, 8^{\text {th }}, 9^{\text {th }}$ and $10^{\text {th }}$ Grade of the SSC, ICSE and CBSE schools.

\section{The Population and the Sample}

This research is being conducted in Secondary Schools in Mumbai and Thane. St. Anthony's High School, Hasanat high School, Orchids International school. A total of 453 students studying from class $6^{\text {th }}$ to $10^{\text {th }}$ formed the sample. Out of the total sample 233 were females and 220 males.

\section{Tools of Research}

For the present study, researcher designed the questionnaire tool in the form of google form. The questions of the tool were ranked from 1 to 5, where 1 meant Factors affecting the academic achievement at a lower scale and 5 meant as factor affecting at a higher scale.

\section{Technique of Data Analysis}

For the current study Likert scale was being used in terms of power of measurement. Descriptive Statistics were used for the current study. Measures of Central tendency, Measures of Variability, Measures of Fiduciary Limits were being used in the Descriptive analysis. In the Inferential Analysis, Parametric and Non -Parametric techniques were used to calculate and present the data. Under Parametric technique, t-test was used to compare the factors with respect to Gender and Grade level. Under Non-Parametric technique Karl Pearson's coefficient of correlation was being used to measure the relationship between the variables.

\section{Analysis and interpretation of the Data}

There is no significant difference between the Attitude of Parents, Attitude of Students, Attitude of 
Peers and Attitude of Teachers affecting the academic achievement of secondary school students with respect to boys and girls.

Table 1: t-Value of the Attitude of Parents, Attitude of Students, Attitude of Peers and Attitude of Teachers, affecting the academic achievement of Secondary school students with respect to boys and girls

\begin{tabular}{|c|c|c|c|c|c|c|c|c|c|c|c|}
\hline Variables & Group & $\mathrm{Nu}$ & nber & & ean & & D & Table & Value & Obtained & Significance \\
\hline \multirow{2}{*}{$\begin{array}{l}\text { Attitude of } \\
\text { Parents }\end{array}$} & \multirow{4}{*}{ Gender } & Boys & Girls & Boys & Girls & Boys & Girls & 0.05 & 0.01 & value of $T$ & I \\
\hline & & \multirow{3}{*}{220} & \multirow{3}{*}{233} & 15.47 & 14.79 & 3.95 & 4.01 & 2.59 & 1.96 & 0.03 & $\begin{array}{l}\text { Not } \\
\text { Significant }\end{array}$ \\
\hline $\begin{array}{l}\text { Attitude of } \\
\text { Students }\end{array}$ & & & & 34.3 & 35.02 & 4.1 & 3.71 & 2.59 & 1.96 & 0.02 & $\begin{array}{l}\text { Not } \\
\text { Significant }\end{array}$ \\
\hline $\begin{array}{l}\text { Attitude of } \\
\text { Peers }\end{array}$ & & & & 9.53 & 9.39 & 3.23 & 3.08 & 2.59 & 1.96 & 0.31 & $\begin{array}{l}\text { Not } \\
\text { Significant }\end{array}$ \\
\hline $\begin{array}{l}\text { Attitude of } \\
\text { Teachers }\end{array}$ & & & & 18 & 18.7 & 3.18 & 2.35 & 2.59 & 1.96 & 0.003 & $\begin{array}{l}\text { Not } \\
\text { Significant }\end{array}$ \\
\hline
\end{tabular}

\section{Interpretation}

From the above Table 1 it can be seen that Attitude of Parents, Attitude of Students, Attitude of Peers and Attitude of Teachers affecting the academic achievement of secondary school students is almost the same in boys and girls.

Table 2: t-Value of the Attitude of Parents, Attitude of Students, Attitude of Peers and Attitude of Teachers affecting the academic achievement of Secondary school students with respect to Grade

\begin{tabular}{|c|c|c|c|c|c|c|c|c|c|c|c|}
\hline Variable & Group & Number & & Mean & & SD & & Table & Value & & \\
\hline \multirow{2}{*}{$\begin{array}{l}\text { Attitude of } \\
\text { Parents }\end{array}$} & \multirow{5}{*}{ Grade } & $6,7,8^{\text {th }}$ & $\begin{array}{l}9^{\text {th }} \& \\
10^{\text {th }}\end{array}$ & $6,7,8^{\text {th }}$ & $\begin{array}{l}9^{\text {th }} \& \\
10^{\text {th }}\end{array}$ & $6,7,8^{\text {th }}$ & $\begin{array}{l}9^{\text {th }} \& \\
10^{\text {th }}\end{array}$ & 0.05 & 0.01 & value of $T$ & Level \\
\hline & & \multirow{4}{*}{202} & \multirow{4}{*}{251} & 15.83 & 14.52 & 3.72 & 4.1 & 2.59 & 1.96 & 0.00025 & $\begin{array}{l}\text { Not } \\
\text { Significant }\end{array}$ \\
\hline $\begin{array}{l}\text { Attitude of } \\
\text { Students }\end{array}$ & & & & 35.2 & 34.19 & 3.36 & 4.27 & 2.59 & 1.96 & 0.003355 & $\begin{array}{l}\text { Not } \\
\text { Significant }\end{array}$ \\
\hline $\begin{array}{l}\text { Attitude of } \\
\text { Peers }\end{array}$ & & & & 9.4 & 9.47 & 3.11 & 3.17 & 2.59 & 1.96 & 0.4 & $\begin{array}{l}\text { Not } \\
\text { Significant }\end{array}$ \\
\hline $\begin{array}{l}\text { Attitude of } \\
\text { Teachers }\end{array}$ & & & & 18.55 & 18.19 & 2.48 & 3.04 & 2.59 & 1.96 & 0.08 & $\begin{array}{l}\text { Not } \\
\text { Significant }\end{array}$ \\
\hline
\end{tabular}

There is no significant difference between the Attitude of Parents, Attitude of Students, Attitude of Peers and Attitude of Teachers affecting the academic achievement of secondary school students with respect to Grade. 
$\mathcal{D}$ D'souza and Magre

\section{Interpretation}

From the above table 2 it can be seen that Attitude of Parents, Attitude of Students, Attitude of Peers and Attitude of Teachers affecting the academic achievement of secondary school students is almost the same in all the Grades.

\section{Correlation of the Factors}

In order to show how closely the variables Attitude of Parents, Attitude of Students, Attitude of Peers and Attitude of Teachers are closely related to each other. Correlation Coefficient $r$ was being measured to show the strength and the direction of a linear relationship between the variables on the scatterplot. The value of $r$ is always between +1 and -1 . The following is the scatterplots of the variables.

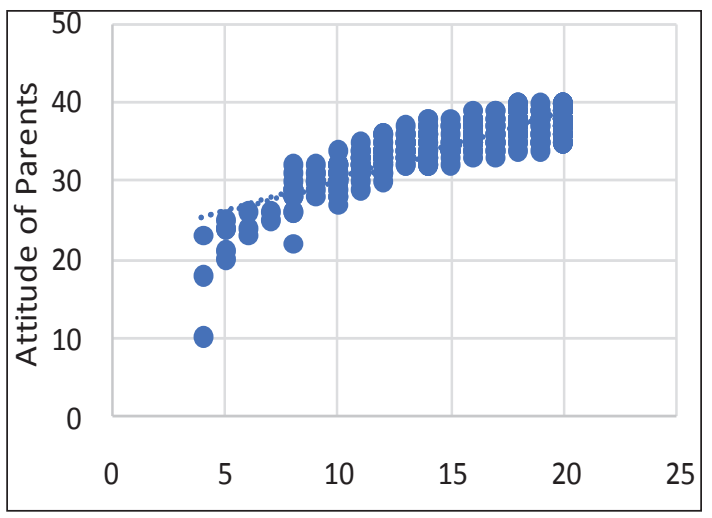

Fig. 1: Correlation of attitude of Parents and Attitude of Students

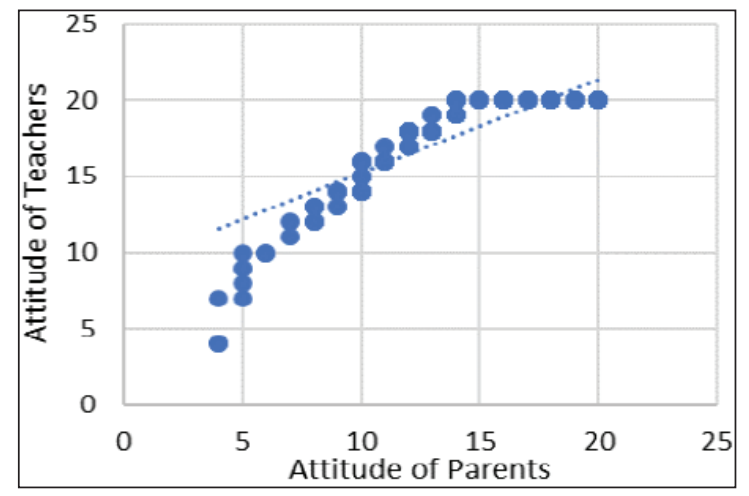

Fig. 3: Correlation of attitude of Parents and Attitude of Teachers

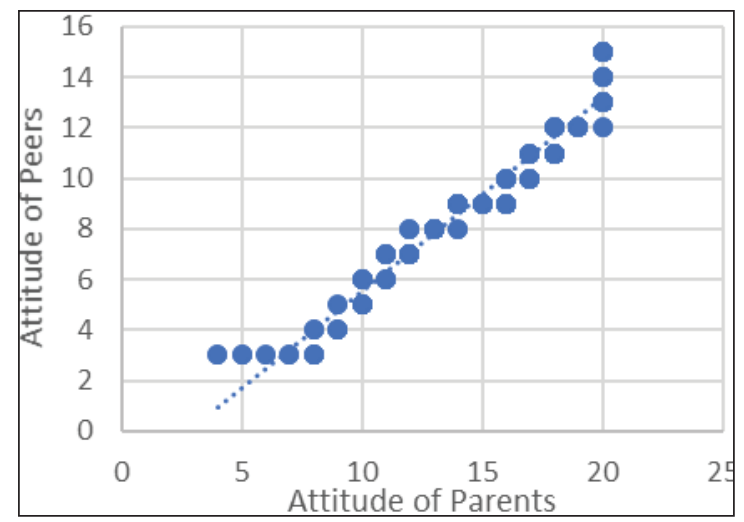

Fig. 2: Correlation of attitude of Parents and Attitude of Peers

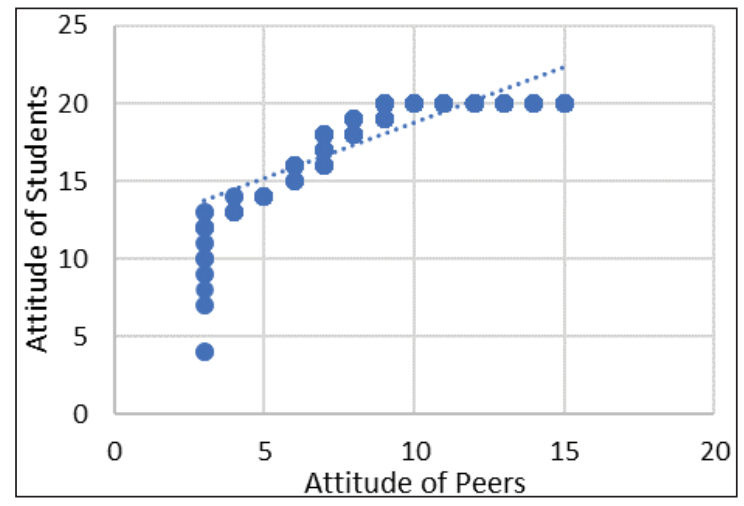

Fig. 4: Correlation of attitude of Peers and Attitude of Students 


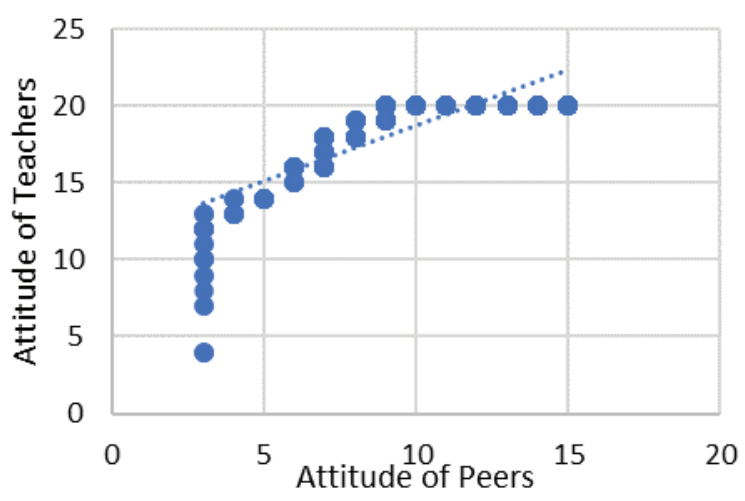

Fig. 5: Correlation of attitude of Peers and Attitude of Teachers

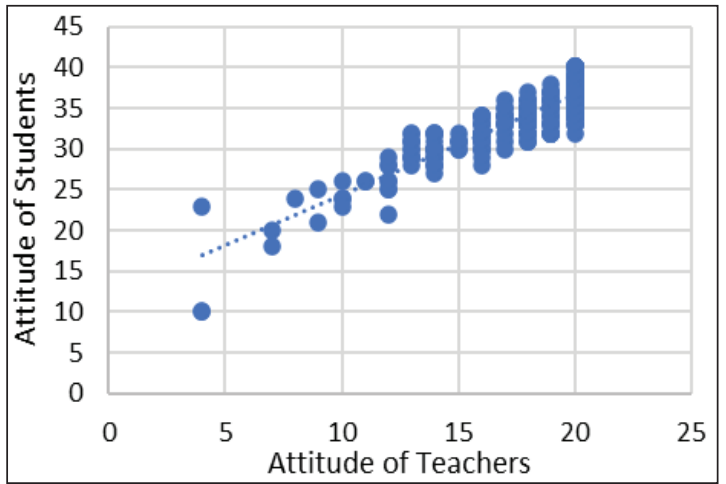

Fig. 6: Correlation of attitude of Students and Attitude of Teachers

\section{Interpretation}

Fig. 1 shows the correlation of 0.84956 . The points fall close to the line, which indicates that there is a large positive relationship between the variables. The relationship is positive because as one variable increases, the other variables also increase. Fig. 2 shows the correlation of 0.96998 . The points fall close to the line, which indicates that there is a large positive relationship between the variables Attitude of Parents and Attitude of Peers. The relationship is positive because as one variable increases, the other variables also increase. Fig. 3 shows the correlation of 0.86846 . The points fall close to the line, which indicates that there is a large positive relationship between the variables Attitude of Parents and Attitude of Teachers. The relationship is positive because as one variable increases, the other variables also increase. Fig. 4 shows the correlation of 0.80946 . The points fall close to the line, which indicates that there is a large positive relationship between the variables Attitude of Peers and Attitude of Students. The relationship is positive because as one variable increases, the other variables also increase. Fig. 5 shows the correlation of 0.80677 . The points fall close to the line, which indicates that there is a large positive relationship between the variables Attitude of Peers and Attitude of Teachers. The relationship is positive because as one variable increases, the other variables also increase. Fig. 6 shows the correlation of 0.89058 . The points fall close to the line, which indicates that there is a large positive relationship between the variables Attitude of Students and Attitude of Teachers. The relationship is positive because as one variable increases, the other variables also increase.

From the above diagrams and correlation to coefficient $r$ it can be seen that Factors affecting the academic achievement of secondary school students are related to each other as when one factors increases the other factors also increase.

\section{CONCLUSION}

We have observed that there is no significant difference in the factors affecting the academic achievement 
of Secondary school students with respect to boys and girls and Grade level. However, in Figure 1, 2, 3, 4, 5, 6 it has been observed that there is a significant relationship between the factors. Thus, it can be said that the factors are related, where one factor increases other factors also increase. From the findings and the discussion of the study we can see that the factors do not necessarily affect the academic achievement of secondary school students. The students have a positive attitude, with Parents supporting them and receiving peers and Teachers support for the academic achievements. This shows that a further study needs to be done on other factors affecting the academic achievement of students. The further studies might help in identifying the other factors affecting the academic achievement of students.

\section{REFERENCES}

1. Apu, G. 2020. Factors Affecting Students Academic Achievement in Chemistry: A Case of Obudu Local Government Area. From SSRN.

2. Chazen, D. 2020. Factors Affecting Students Academic Performance in 2020-2021. From Verbit.ai: https://verbit. ai/factors-affecting-students-academic-performance/

3. Cherry, K. 2021. Attitudes and Behaviour in Psychology. From verywellmind.com: https://www.verywellmind. com/attitudes-how-they-form-change-shape-behavior-2795897

4. Chinmayee, Manohar and Sayeeqa. 2016. Analysis of Factors affecting student academic performance using Data mining Techniques. IJARIIE, 1(5).

5. Definition of Factor. (n.d.). From Collinsdictionary.com: https://www.collinsdictionary.com/dictionary/english/factor

6. Dev, M. 2016. Factors Affecting the Academic Achievement: A study of Elementary School Students of NCR Delhi, India. Journal of Education and Practice, 7(4).

7. Ebenuwa-Okoh, E.E. 2010. Influence of Age, Financial Status, and Gender on Academic Performance among Undergraduates. Journal of Psychology, 1(2): 99-103.

8. Hunter, R. 1965. Some Factors Affecting Undergraduate Academic Achievement. CMAJ Journal, 92(14): 732-736.

9. Iman, S. 2017. Factors affecting students'academic achievement and experiences. From Grin.com: https://www. grin.com/document/364659

10. Lawal, B. 2010. Factors affecting academic achievement of students in Senior School Certificate Examination in Christian Religious Knowledge. African Research Review, 4(17), 420-433.

11. Moore, P.J. 2019. Academic Achievement. An International Journal of Experimental Educational Psychology, 39(8): 981-983.

12. Mushtaq, I. 2012. Factors Affecting Students'Academic Performance. Global Journal of Management and Business Research, 12(9).

13. Olufemi, O.T. 2018. Factors Affecting Students Academic Performance in Colleges of Education in Southwest, Nigeria. British Journal of Education, 6(10): 43-56.

14. Olufemi, O.T., Adediran, A.A. and Oyediran, W.O. 2018. Factors Affecting Students' Academic Performance in Colleges of Education in Soutwest, Nigeria. British Journal of Education, 6(10): 43-56. 
15. Ragin, S. 2020. Trick or Cheat? 10 Things Affecting Students'Academic Performance. From collegeraptro.com: https://www.collegeraptor.com/find-colleges/articles/tips-tools-advice/trick-cheat-10-things-affecting-studentsacademic-performance/

16. Ragin, S. (n.d.). Trick or $c$.

17. Sangkapan, J. and Laeheem, K. (n.d.). Factors Affecting Students Academic Achievement into Probation.

18. Silva, V. 2020. 8 Factors that Affect Students'Motivation in Education. From Built by me: https://www.builtbyme. com/students-motivation-in-education/

19. Sirin, Y.E. and Sahin, M. 2020. Investigation of Factors Affecting the Achievement of University Students with Regression Analysis: School of Physical Education and Sport Example. Sage Journals, 10(1).

20. Son, B. and Cho, Y. 2020. An Analysis of Factors that Affect Academic Achievement in Globalized Enviornment. The Journal of Industrial Distribution and Business, 11(6): 7-17.

21. Steinmayr, R. 2020. Academic Achievement. From Oxford Bibliographies: https://www.oxfordbibliographies.com/ view/document/obo-9780199756810/obo-9780199756810-0108.xml 
